\title{
PENGEMBANGAN DAN IMPLEMENTASI E-LEARNING MENGGUNAKAN MOODLE DAN VICON UNTUK PELAJARAN PEMROGRAMAN WEB DI SMK
}

\author{
R. Hafid Hardyanto \\ Jurusan Teknik Informatika Universitas PGRI Yogyakarta \\ hafid234@yahoo.co.id \\ Herman Dwi Surjono \\ Universitas Negeri Yogyakarta \\ hermansurjono@yahoo.com
}

\begin{abstract}
Abstrak
Tujuan penelitian ini adalah untuk: (1) mengembangkan produk portal e-learning menggunakan LMS Moodle dengan vicon, (2) mengetahui kelayakan portal e-learning, (3) mengetahui hasil belajar peserta didik dalam pembelajaran menggunakan portal e-learning, dan (4) mengetahui motivasi belajar peserta didik dalam pembelajaran menggunakan portal e-learning. Penelitian ini merupakan penelitian pengembangan yang diadaptasi dari model pengembangan dan desain multimedia yang dikembangkan oleh Alessi \& Trollip. Subjek penelitian ini adalah siswa kelas $X$ kompetensi keahlian Rekayasa Perangkat Lunak di SMK Muhammadiyah 1 Bambanglipuro, teknik pengambilan sampel dilakukan secara acak. Uji coba produk pengembangan meliputi tes alfa, tes beta, dan implementasi uji lapangan. Hasil penelitian menghasilkan: (1) produk portal e-learning yang dikembangkan menggunakan LMS Moodle terintegrasi dengan BigBlueButton, sehingga memungkinkan pengguna untuk melakukan video conference; (2) kelayakan portal e-learning menggunakan LMS Moodle dengan vicon di SMK Muhammadiyah 1 Bambanglipuro, validasi alfa dikategorikan baik, uji beta dikategorikan baik, validasi ahli materi dikategorikan baik; (3) hasil belajar peserta didik dalam pembelajaran menggunakan portal e-learning, kelas kontrol dan kelas eksperimen sama; (4) motivasi peserta didik dalam pembelajaran menggunakan portal e-learning, kelas kontrol dan kelas eksperimen sama.
\end{abstract}

Kata kunci: e-learning, moodle, vicon, pemrograman web

\section{DEVELOPING AND IMPLEMENTING E-LEARNING USING MOODLE AND VICON FOR THE WEB PROGRAMMING SUBJECT AT SMK}

\author{
Abstract
}

The aims of this research were to: (1) develop e-learning portal using LMS moodle and vicon, (2) know the feasibility of the e-learning portal using LMS Moodle and vicon, (3) know the learning outcomes of students in learning using $e$-learning, and (4) know the motivation of learners in learning using e-learning. This research was development research that was adapted from Alessi \& Trollip Development and Multimedia Design Model. The subjects of this research were students of class X SMK Muhammadiyah 1 Bambanglipuro, with competency skills Soft Engineering. The sampling technique was random sampling. The developed product try-out included three stages, the alpha test, beta test, and implementation of field tests. The result of this research showed that: (1) e-learning product that was developed using Moodle integrated with BigBlueButton, allowed users to do video conferencing, (2) the feasibility of e-learning using moodle and the video conference at SMK Muhammadiyah 1 Bambanglipuro: for the mean score of validation was categorized good; the mean score of beta test was categorized good; and according to the expert the materia was categorised good. (3) The results of learners in learning using e-learning moodle, showed no difference betwen the conrtol class and the experimental class.. (4) The motivation of learners in learning using e-learning in the control class and that in experimental class were equal.

Keywords: e-learning, moodle, vicon, web programming 



\section{PENDAHULUAN}

Perkembangan teknologi informasi yang terjadi di negara ini semakin maju seiring berkembangnya era pasar global. Perkembangan teknologi informasi banyak digunakan untuk membantu menunjang aktivitas kehidupan manusia. Di dunia pendidikan kehadiran teknologi informasi menjadi salah satu pilihan untuk menyelenggarakan program pendidikan. Pemanfaatan internet dalam bentuk media pembelajaran berbasis web merupakan salah satu bentuk e-learning yang pada era ini sedang populer dikembangkan oleh berbagai lembaga pendidikan. Teknologi internet yang memiliki sifat interaktif, fleksibel, dan tidak terbatas ruang dan waktu diharapkan menjadi salah satu media pembelajaran yang unggul.

Pemanfaatan berbagai media, komputer, dan teknologi informasi telah menjadi bahan pertimbangan para guru untuk pengembangan penyelenggaraan pembelajaran di kelas. Dalam proses adaptasi dengan teknologi informasi yang berkembang pesat, mau tidak mau pergeseran paradigma belajar harus berubah, dari teaching community menjadi learning community. Menurut Surjono (1998, p.35), perkembangan komputer yang begitu pesat mengharuskan para pendidik untuk mengoptimalkan fungsi dan aplikasinya dalam bidang pendidikan. Menurut Tandirerung dalam hal kebermanfaatan, e-learning sangat bermanfaat menurut guru dan bermanfaat menurut siswa. Ada sumbangan daya dukung e-learning dan kebermanfaatan e-learning secara bersama-sama terhadap implementasi e-learning.

Salah satu contoh Web Based Learning (WBL) dalam dunia pendidikan adalah pemanfaatan e-learning dalam pembelajaran. Mayer (2011, p.1); Moore et al. (2011, p.129); Zhang, Zhou, dan Briggs (2006, p.15) mengatakan bahwa e-learning adalah pembelajaran yang dilakukan dengan media komputer atau perangkat elektronik untuk mendukung pembelajaran. Pembelajaran dapat melalui CD ROM (pembelajaran off line), ataupun melalui jaringan intra net. Menurut Rosenberg (2009, p.35), e-learning adalah peralatan teknologi komputer yang digunakan untuk meningkatkan proses belajar dan mengajar. E-learning juga dimanfaatkan untuk menyampaikan informasi atau solusi untuk meningkatkan pe- ngetahuan. Naidu (2003, p.11) menambahkan bahwa penerapan e-learning sangat bermanfaat bagi pembelajaran karena sifatnya yang fleksibel, yang memungkinkan user untuk mengakses informasi dan sumber belajar tanpa terbatas ruang dan waktu. Tujuan dari pembelajaran e-learning adalah tidak membatasi siswa dalam belajar karena terhambat waktu dan jarak yang tidak memungkinkan untuk dilakukan pembelajaran secara langsung. Henderson (2003, p.29), mengemukakan 3 macam tipe pembelajaran dengan $e$ learning: (1) Synchronous, yaitu sekelompok mahasiswa bertemu dengan instruktur melalui internet, user online pada saat yang bersamaan ketika mereka berkomunikasi satu dengan yang lain, instruktur dapat berinteraksi dengan siswa, siswa dapat berinteraksi dengan siswa lain; (2) Self-direct, yaitu siswa bertindak sendiri untuk belajar, tidak ada guru/instruktur, teman yang berinteraksi dengannya; (3) Asynchronous, gaya belajar ini merupakan gaya belajar kolaboratif, sekelompok siswa bertemu dengan guru melaui internet dan dapat berkomunikasi, namun tidak selalu online pada saat yang bersamaan. Siswa dapat berkomunikasi dengan meninggalkan pesan yang dapat direspon selang beberapa waktu. Meriläinen et al. (2013, p.20) menambahkan bahwa pembelajaran online dapat membuat siswa aktif. Salah satu $L M S$ yang banyak digunakan untuk membangun portal e-learning adalah moodle. Menurut Saraswat (2014, p.1), Zrakić et al. (2012, p.326), Thabit (2013, p.96), moodle adalah sistem manajemen pembelajaran yang berguna dan fleksibel dan dapat menambah pengalaman belajar online. Moodle dapat digunakan untuk menyampaikan pembelajaran kepada siswa dengan menarik, moodle juga kaya akan kolaborasi pembelajaan dengan media lain. Moodle memungkinkan pengguna untuk menjadi pembelajar aktif. Dalam moodle dapat disisipkan gambar, halaman web, quiz dan animasi. Syamsuddin dan Aimin (2014, p.20) menambahkan, fitur yang terdapat dalam moodle meliputi (1) course content management, (2) synchronous and asynchronous communication, (3) the uploading of content, (4) the return of students' work, (5) peer assessment, (6) student administration, (7) the collection and organization of students' grades, (8) online questionnaires, (9) online quizzes, dan (10) tracking tools. 
Pada penelitian ini desain e-learning yang digunakan adalah menggunakan fasilitas video conference (vicon). Menurut Alberta (2006, p.21), Vicon juga dapat meningkatkan aktifitas pembelajaran dan memfasilitasi diskusi kolaboratif. Menurut Candarli dan Yuksel (2012, p.357), penerapan vicon di sekolah menegah banyak keuntungannya, seperti meningkatkan motivasi, meningkatkan interaksi dan kompetensi untuk berkomunikasi. Penelitian yang dilakukan Candarli dan Yuksel (2012, p.358) menemukan bahwa 80\% responden siswa menyukai dan nyaman dengan pembelajaran melalui vicon yang diterapkan di sekolah. Karal Cebi, Turgut, (2011, p.276) menambahkan bahwa pembelajaran melalui vicon disukai siswa. Siswa tertarik kepada pembelajaran melalui vicon. Vicon juga dapat menambah motivasi belajar siswa. Pembelajaran melalui vicon sebaiknya tidak didominasi oleh tatap muka ketika terjadi vicon, melainkan dikolaborasikan dengan diskusi dan tanya jawab. Gough (2006, p.3) mengatakan bahwa vicon mempunyai potensi besar dalam pembelajaran untuk diterapkan di sekolah dan perguruan tinggi. Potensi terletak dalam menciptakan kesempatan untuk memfasilitasi pembelajaran yang lebih efektif pada pembelajaran yang mempunyai hambatan jarak. Lebih jauh Gough menjelaskan keberhasilan vicon tergantung pada sikap siswa, tutor, dan metode yang diadopsi. Alasan utama dalam menggunakan vicon adalah jarak dan waktu yang tidak memungkinkan seorang guru untuk hadir di dalam kelas. Paderanga (2014, p.113) menambahkan vicon kini telah diterapkan di sekolah-sekolah untuk mengoptimalkan pembelajaran. Vicon dapat meningkatkan kemampuan berkomunikasi dan kemampuan presentasi antar siswa. Vicon memungkinkan siswa untuk belajar dan berinteraksi dengan guru atau siswa lain di tempat yang lain tanpa harus meninggalkan kelas.

Salah satu software vicon yang ada adalah BigBlueButton. Menurut Sahana (2015, p.224), BigBlueButton adalah sistem dari web conference yang dikembangkan untuk pembelajaran jarak jauh. BigBlueButton memungkinkan untuk bertukar suara dan gambar, termasuk chat, presentasi, bertukar dokumen, dan dekstop sharing sehingga pengguna dapat bertatap muka dari tempat yang berbeda. Menurut Seeling (2010, p.1), Laipaka dan
Sarwoko (2011, p.68), Bello et al. (2014, p.59), Meegama et al. (2015, p.1) BigBlueButton adalah sebuah software open source yang menyediakan sistem web conferencing yang memungkinkan pengguna dapat berinteraksi dari tempat lain. BigBlueButton berupa plug in yang dapat dipadukan dengan moodle. Melalui BigBlueButton pembelajaran dapat dilakukan tanpa terkendala jarak. BigBlueButton menurut web pengembang BigBlueButton, bigbluebutton.org. adalah sebuah system open source web conferencing dengan tujuan utama untuk pembelajaran jarak jauh. Bigbluebutton dapat menghandel pertukaran audio dan video, presentasi dengan fasilitas whiteboard, termasuk di dalamnya pengguna dapat menggambar, memperbesar gambar yang dikirim, obrolan pribadi ataupun umum, pertukaran desktop, mengintegrasikan VoIP menggunakan freeSwitch, dan mendukung untuk presentasi dengan format $p d f$, dan Microsoft office.

Sekolah Menengah Kejuruan (SMK) merupakan pendidikan pada jenjang pendidikan menengah yang mengutamakan pengembangan kemampuan siswa untuk dapat bekerja dalam bidang tertentu. Peran teknologi informasi di era global tidak dapat dipisahkan dari dunia pendidikan khususnya pendidikan menengah kejuruan. Teknologi informasi yang berlangsung sangat cepat memaksa pendidikan menengah kejuruan untuk beradaptasi dengan kebutuhan era global. Hal ini berimbas pada penyediaan sarana prasarana sekolah yang mau tidak mau harus mengikuti perubahan di era global salah satunya adalah ketersediaan koneksi internet.

Koneksi internet pada pendidikan kejuruan merupakan sarana wajib yang dimiliki SMK untuk melengkapi sarana prasarana di era globalisasi. Sarana prasarana SMK khususnya koneksi internet di berbagai SMK saat ini sudah dapat dikatakan memadai. SMK Muhammadiyah 1 Bambanglipuro telah melengkapi sarana prasarana dengan koneksi internet. Dengan koneksi internet transfer informasi teknologi menjadi lebih cepat dan efisien. Hanya dengan duduk di depan komputer siswa/guru dapat mengakses informasi menjadi lebih cepat dan tidak terbatas oleh ruang dan waktu.

Ketersediaan internet di SMK bukan berarti tanpa kendala, kendala yang dihadapi adalah banyak SMK yang mempunyai fasili- 
tas internet memadai, namun pemanfaatannya kurang. Salah satu SMK unggulan dengan fasilitas internet memadai adalah SMK Muhammadiyah 1 Bambanglipuro Bantul. Koneksi internet sebagian besar dipakai siswa dan guru hanya untuk browsing membuka situs sosial media, membuka situs berita, walaupun ada sebagian guru yang memanfaatkan koneksi internet sebagai media pembelajaran tambahan. Di samping itu, faktor ketergantungan siswa terhadap guru juga dinilai masih tinggi. Kurangnya siswa dalam pemanfaatan sarana khususnya koneksi internet untuk menunjang pembelajaran mengakibatkan ketergantungan siswa terhadap guru masih tinggi.

Kurangnya pemanfaatan koneksi internet di SMK Muhammadiyah 1 Bambanglipuro dapat dilihat dari minimnya guru yang memanfaatkan internet sebagai alternatif media pembelajaran. Berdasarkan prasurvei yang telah dilakukan oleh peneliti, sekolah sudah mempunyai fasilitas komputer dan jaringan internet yang cukup baik, hanya saja saat ini fasilitas internet tersebut kurang dimanfaatkan dalam pembelajaran. Menurut kepala jurusan RPL SMK Muhammadiyah 1 Bambanglipuro, bapak Aris Muthohar, hal ini dapat terjadi karena berbagai faktor, salah satunya belum adanya portal e-learning di SMK Muhamadiyah 1 Bambanglipuro. Melalui penelitian ini diharapkan dapat memperoleh gambaran umum tentang pengembangan dan penerapan portal e-learning di SMK Muhammadiyah 1 Bambanglipuro.

Berdasarkan latar belakang masalah tersebut, maka penelitian ini bertujuan untuk: (1) mengembangkan portal e-learning dengan vicon di SMK Muhammadiyah 1 Bambanglipuro Bantul, (2) mengetahui kelayakan produk portal e-learning yang dikembangkan di SMK Muhammadiyah 1 Bambanglipuro, (3) mengetahui hasil belajar peserta didik dalam pembelajaran menggunakan e-learning, (4) mengetahui motivasi peserta didik dalam pembelajaran menggunakan e-learning .

\section{METODE PENELITIAN}

Penelitian ini menggunakan model penelitian pengembangan yang diadaptasi dari model pengembangan dan desain multimedia yang dikembangkan oleh Alessi \& Trollip. Model pengembangan Alessi \& Trollip ini mempunyai tiga fase yang meliputi perenca- naan (planning), desain (design), dan pengembangan (development). Adapun skema pengembangan portal e-learning di SMK Muhammadiyah 1 Bambanglipuro adalah sebagai berikut.

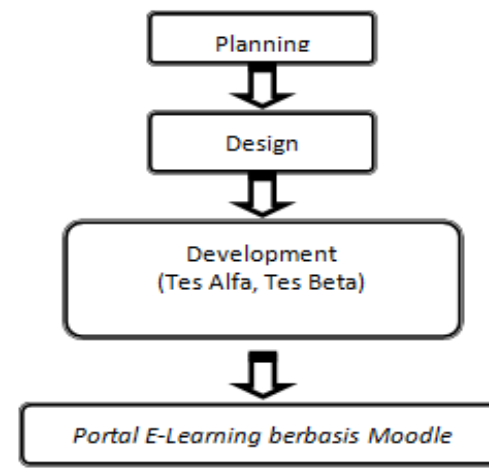

\section{Gambar 1. Skema Pengembangan Diadaptasi dari Alessi dan Trollip} (2001)

Penelitian ini dilaksanakan pada SMK Muhammadiyah 1 Bambanglipuro. Waktu penelitian dimulai pada bulan Oktober 2014Desember 2014. Subjek pada penelitian ini adalah siswa kelas X SMK Muhammadiyah 1 Bambanglipuro kompetensi keahlian Rekayasa Perangkat Lunak. Populasi siswa berjumlah 72, dipilih 32 kelas kontrol dan 32 kelas eksperimen. Teknik pengambilan sampel dilakukan secara acak.

Teknik pengumpulan data menggunakan angket dan tes. Angket digunakan untuk validasi instrumen media dan materi yang dikembangkan, dan tes digunakan untuk mendapatkan data hasil belajar pada penggunaan media hasil pengembangan.

Data yang diperoleh dari penelitian ini ada 2 macam, yaitu data kualitatif dan data kuantitatif. Data kualitatif diperoleh dari masukan, kritik dari ahli materi, ahli media, dan peserta didik subjek uji coba yang dihimpun untuk memperbaiki produk yang didesain dan dikembangkan.

Teknik analisis data kuantitatif dalam penelitian ini menggunakan statistik deskriptif yang berupa pernyataan sangat tidak baik, tidak baik, cukup, baik, dan sangat baik yang diubah menjadi data kuantitatif dengan skala 5 yaitu penskoran dari 1-5. Data hasil belajar diperoleh dari penerapan media hasil pengembangan secara luas yang dimaksudkan untuk mengetahui pengaruh media yang dikembangkan terhadap hasil belajar siswa. Analisis 
data hasil belajar dilakukan dengan membandingkan hasil belajar kelompok eksperimen dengan kelompok kontrol. Data hasil belajar kelompok kontrol dan kelompok eksperimen dibandingkan kemudian dianalisis dengan menggunakan uji t. Sebelum uji t dilakukan terlebih dahulu dilakukan uji prasyarat yaitu uji normalitas dan uji homogenitas.

\section{HASIL PENELITIAN DAN PEMBAHASAN}

\section{Hasil Pengembangan Produk Awal}

\section{Perencanaan}

Langkah yang dilakukan pada tahap ini adalah menentukan ruang lingkup kajian (define the scope), mengidentifikasi karakteristik siswa (identify learner characteristics), membangun batasan (establish the constraints) dalam hal ini membatasi kompetensi dasar, anggaran biaya (cost the project), merencanakan pembelajaran, menentukan sumber-sumber (determine and collect resources), dan conduct initial brainstorming.

\section{Hasil Desain}

Pada tahap ini peneliti melakukan analisis konsep dan tugas yang berkaitan dengan materi, yaitu dengan cara menyiapkan semua bahan ajar yang berkaitan dengan materi pemrograman web, silabus, RPP, tabel spesifikasi soal, kisi-kisi penulisan soal serta mempersiapkan soal uji kompetensi yang akan digunakan untuk pre-test dan post-test. Soal uji kompetensi yang akan digunakan untuk pretest dan post-test diujicobakan terlebih dahulu terhadap 36 siswa kelas XI program keahlian Rekayasa Perangkat Lunak di SMK Muhammadiyah 1 Bambanglipuro. Uji coba soal ini untuk mengetahui tingkat kesulitan soal yang akan digunakan. Dari 25 soal yang diujicobakan peneliti memilih 20 butir soal yang mewakili seluruh materi yang diujicobakan.

\section{Hasil Pengembangan Produk}

Hasil pengembangan produk berupa portal e-learning SMK Muhammadiyah Bambanglipuro. Portal e-learning diberi nama $E$ Learning SMK Muhammadiyah 1 Bambanglipuro. Adapun fasilitas yang tersedia pada pembelajaran dengan menggunakan portal $e$ learning diantaranya adalah forum diskusi, chating, latihan, tugas, quiz, serta tes hasil belajar atau uji kompetensi online. Halaman depan portal e-learning SMK Muhammadiyah 1 Bambanglipuro disajikan pada Gambar 2.

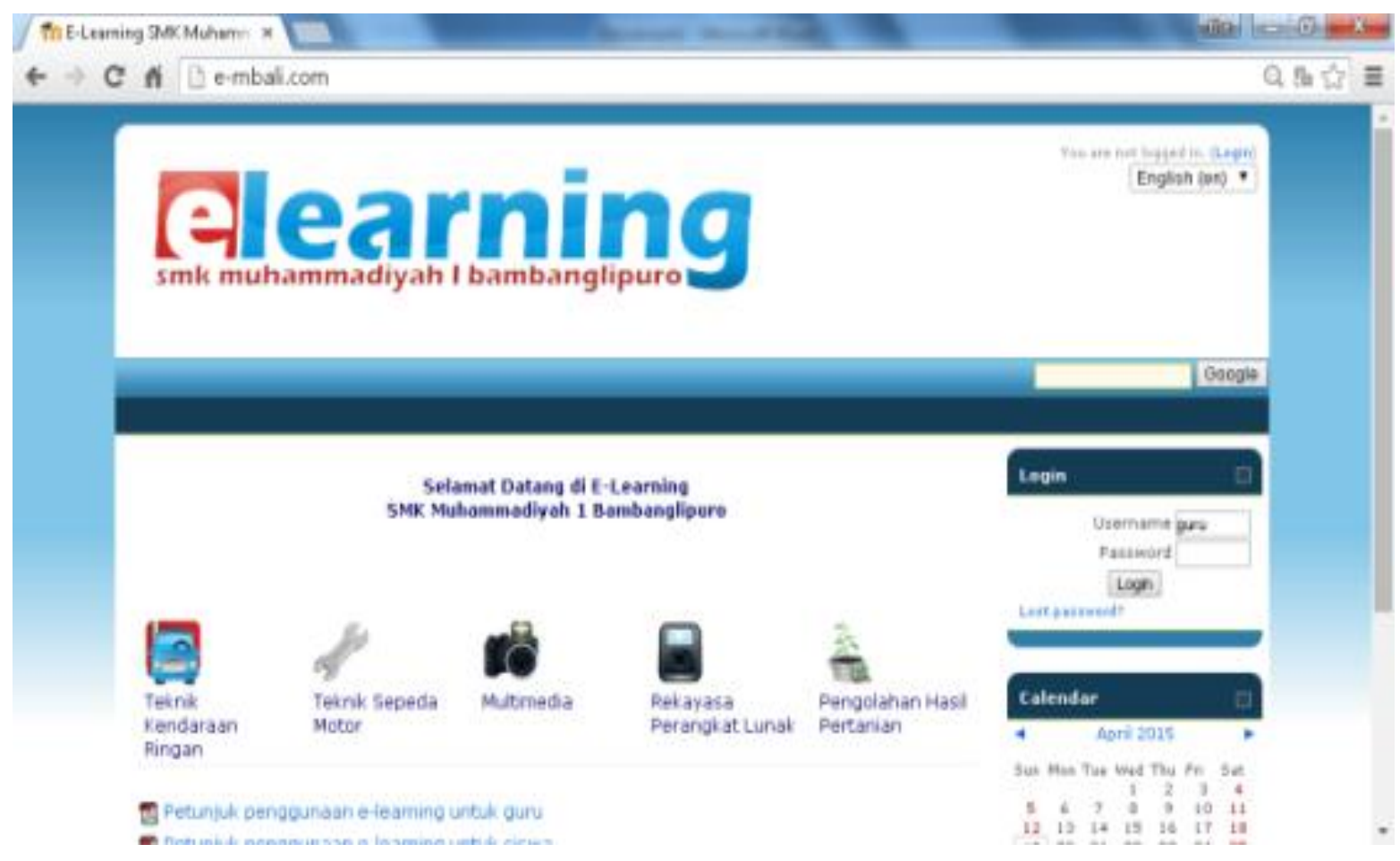

Gambar 2. Halaman Depan Portal E-Learning 


\section{Hasil Uji Coba Produk}

Dalam uji coba produk pengembangan portal e-learning menggunakan vicon di SMK Muhammadiyah Bambanglipuro diperoleh tiga jenis data, yaitu data uji alfa, data uji beta, dan data evaluasi sumatif.

\section{Analisis Data Hasil Validasi Ahli Media (Tes Alfa)}

Berdasarkan validasi dari ahli media, diketahui kualitas portal e-learning dengan vicon yang sedang dikembangkan adalah baik, dengan rerata penilaian sebesar 4,05. Data hasil uji alfa ditampilkan pada Tabel 1 .

Tabel 1. Angket Validasi Ahli Media

\begin{tabular}{|c|c|c|}
\hline No. & Indikator & Skor \\
\hline 1. & $\begin{array}{l}\text { Kemudahan penggunaan } \\
\text { program }\end{array}$ & Baik \\
\hline 2. & Susunan tampilan (interface) & Baik \\
\hline 3. & Kualitas teks & Cukup \\
\hline & Kualitas gambar & Baik \\
\hline 5. & Pengaturan ruang (space) & Baik \\
\hline 6. & Petunjuk navigasi & Baik \\
\hline 7. & $\begin{array}{l}\text { Kemudahan penggunaan } \\
\text { navigasi }\end{array}$ & Baik \\
\hline 8. & Tugas (Assignment) & Sangat baik \\
\hline & $\begin{array}{l}\text { Fasilitas belajar kolaboratif } \\
\text { (chat, forum) }\end{array}$ & Sangat baik \\
\hline 10. & Quiz & Sangat baik \\
\hline 11. & Upload file & Sangat baik \\
\hline 12. & $\begin{array}{l}\text { Penggunaan program secara } \\
\text { normal }\end{array}$ & Sangat baik \\
\hline 13. & $\begin{array}{l}\text { Penggunaan program secara } \\
\text { tidak normal (tekan } \\
\text { sembarang tombol) }\end{array}$ & Sangat baik \\
\hline 14. & $\begin{array}{l}\text { Dijalankan dengan browser } \\
\text { lain }\end{array}$ & Cukup \\
\hline 15. & Kelengkapan materi & Cukup \\
\hline & Sumber belajar lain & Cukup \\
\hline 17. & Kualitas gambar & Cukup \\
\hline 18. & Kualitas suara & Baik \\
\hline 19. & Fitur presentasi & Baik \\
\hline & Fitur Teks & Baik \\
\hline & Rerata penilaian & Baik \\
\hline
\end{tabular}

Dari penilaian ahli diketahui bahwa butir kualitas teks, dijalankan dengan browser lain, kelengkapan materi, sumber belajar lain, dan kualitas gambar pada kategori cukup. Hal ini kemudian diperbaiki peneliti dengan me- nambah materi sumber belajar lain dan mengupgrade browser yang digunakan. Untuk kualitas gambar diperbaiki dengan menambah resolusi gambar.

\section{Analisis Data Hasil Validasi Ahli Materi}

Validasi yang dilakukan oleh ahli materi mencakup komponen pendahuluan, penyajian informasi, pendalaman materi, partisipasi siswa, umpan balik dan penilaian. Data yang diperoleh dari hasil validasi oleh ahli materi dikonversikan ke dalam skala lima. Berdasarkan hasil olah data, dari 15 butir yang divalidasi oleh ahli materi, kriteria penilaian dari ahli materi termasuk dalam kategori baik, dengan rerata skor 3,53. Hasil penilaian ahli materi disajikan pada Tabel 2 .

Tabel 2. Tabel Validasi Ahli Materi

\begin{tabular}{|c|c|c|}
\hline No. & Komponen Pembelajaran & Skor \\
\hline & Pemberian motivasi awal & Cukup \\
\hline 2. & Perumusan tujuan pembelajaran & Baik \\
\hline 3. & Penyajian ju & Baik \\
\hline $4 .$. & Kelengkapan tabel atau ilustrasi & Baik \\
\hline 5. & Penggunaan analogi yang sesuai & Cukup \\
\hline 6. & $\begin{array}{l}\text { Materi menarik/mengundang } \\
\text { perhatian siswa }\end{array}$ & Baik \\
\hline 7. & Penggunaan contoh & Baik \\
\hline & $\begin{array}{l}\text { Kesesua } \\
\text { karakter }\end{array}$ & aik \\
\hline & $\begin{array}{l}\text { Relevansi tes dengan materi yang } \\
\text { tersaji }\end{array}$ & Baik \\
\hline 10. & Penyediaan jawaban & Cukup \\
\hline 11. & Contoh penyelesaian jawaban & Cukup \\
\hline & $\begin{array}{l}\text { Tanggapan atas jawaban siswa } \\
\text { yang salah }\end{array}$ & Cukup \\
\hline & $\begin{array}{l}\text { Informasi transfer hasil belajar } \\
\text { untuk aktifitas lain }\end{array}$ & Cukup \\
\hline 14. & Tugas, quiz & Cukup \\
\hline & $\begin{array}{l}\text { Penyediaan soal pretest dan post } \\
\text { test }\end{array}$ & Baik \\
\hline & & Baik \\
\hline
\end{tabular}

Hasil validasi ahli materi butir pemberian motivasi awal, penggunaan analogi yang sesuai, umpan balik, aktivitas tindak lanjut dalam kategori cukup. Hal ini diperbaiki peneliti dengan menambah motivasi awal siswa, memperbaiki umpan balik, dan menambah aktivitas tindak lanjut. Setelah diperbaiki 
kemudian dikonsultasikan dengan ahli dan guru pengampu mata pelajaran, selanjutnya materi digunakan untuk penelitian.

\section{Analisis Data Hasil Uji Beta}

Analisis dilakukan berdasarkan data yang diperoleh dari uji beta pada siswa. Uji beta dilakukan dengan melibatkan 9 orang dari siswa program keahlian rekayasa perangkat lunak. Siswa yang dipilih 3 orang berkemampuan sedang, 3 orang berkemampuan tinggi, dan 3 orang berkemampuan rendah. Dari data tersebut dapat diketahui kualitas produk portal e-learning dengan vicon yang sedang dikembangkan. Tanggapan siswa yang mengikuti uji beta terhadap produk portal $e$ learning dengan vicon disajikan pada Tabel 3.

Tabel 3. Prosentase Uji Beta

\begin{tabular}{clcc}
\hline No. & Kriteria & Frekuensi & $(\%)$ \\
\hline 1. & Sangat baik & 39 & 21,67 \\
2. & Baik & 80 & 44,44 \\
3. & Cukup & 60 & 33,33 \\
4. & Tidak baik & 1 & 0,56 \\
5. & Sangat tidak baik & 0 & 0 \\
\hline Jumlah & 180 & 100 \\
\hline
\end{tabular}

Tanggapan komentar siswa pada uji beta meliputi tulisan dan gambar pada bagian fitur presentasi yang terlalu kecil. Hal ini disebabkan ukuran browser pada saat uji beta yang kecil. Komentar selanjutnya yaitu mengenai layar pada video conference yang kecil. Hal tersebut dapat diperbaiki dengan mengganti mode video conference dengan cara mengklik tombol maximize yang ada pada fitur vicon.

\section{Data Hasil Belajar}

Setelah revisi uji beta selesai, produk pengembangan digunakan dalam pembelajaran nyata. Untuk mengetahui perbedaan hasil pembelajaran dari desain portal e-learning dengan vicon, pembelajaran dilakukan pada dua kelas, yaitu kelas kontrol menggunakan pembelajaran dengan portal e-learning tanpa fasilitas vicon. Kelas eksperimen menggunakan pembelajaran dengan portal e-learning dengan fasilitas vicon. Penilaian hasil belajar dalam pembelajaran nyata dilakukan secara formal, yaitu dengan memberikan tes kepada peserta didik sebanyak dua kali, baik pada kelas kontrol maupun kelas eksperimen. Data nilai pretest diperoleh dari nilai sebelum penerapan produk pengembangan, sedangkan nilai data post test diperoleh dari nilai setelah penerapan produk pengembangan.

\section{Data Hasil Belajar Kelas Kontrol}

Data nilai tes sumatif pembelajaran nyata dari 32 peserta didik kelas kontrol selanjutnya dihitung dan dikonversi ke data kualitatif skala lima. Data hasil belajar kelas kontrol dapat ditampilkan pada Tabel 4.

Tabel 4. Tabulasi Data Pretest dan Post Test Kelompok Kontrol

\begin{tabular}{lcc}
\hline Keterangan & Pretest & Post test \\
\hline Nilai tertinggi & 87 & 88 \\
Nilai terendah & 76 & 76 \\
Mean & 80,78 & 81,75 \\
Median & 80 & 81 \\
Mode & 78 & 80 \\
\hline Jumlah & 2585 & 2616 \\
\hline
\end{tabular}

Berdasarkan tabulasi data untuk pretest diatas diketahui bahwa hasil belajar peserta didik yang masuk pada kriteria sangat baik berjumlah 15 , sedangkan peserta didik pada kriteria baik berjumlah 17 siswa. Sedangkan berdasarkan hasil belajar pada post test diketahui bahwa 18 peserta didik pada kriteria sangat baik, dan 14 peserta didik pada kriteria baik. Dari data hasil belajar kelompok kontrol diketahui ada peningkatan nilai hasil belajar antara pretest dan post test. Hasil peningkatan diketahui berjumlah 31 poin, artinya ada peningkatan hasil belajar pada kelompok kontrol.

\section{Data Hasil Belajar Kelas Eksperimen}

Data nilai hasil tes sumatif pembelajaran nyata dari 32 peserta didik kelas eksperimen selanjutnya dihitung dan di konversi ke data kualitatif skala lima. Data hasil belajar kelas eksperimen disajikan pada Tabel 5.

Data hasil belajar siswa kelompok eksperimen yaitu, saat pretest 15 peserta didik masuk dalam kategori sangat baik, dan 17 orang masuk dalam kategori baik. Data hasil belajar post test, 21 peserta didik masuk dalam kategori sangat baik, dan 11 orang masuk 
dalam kategori baik. Dari data hasil belajar kelompok eksperimen terjadi perbedaan nilai antara pre test dan post test yang bernilai positif sebesar 59 poin. Hal ini dapat disimpulkan bahwa ada peningkatan hasil belajar pada kelas eksperimen.

Tabel 5. Tabulasi Data Pretest dan Post Test Kelompok Eksperimen

\begin{tabular}{lcc}
\hline Keterangan & Pretest & Post test \\
\hline Nilai tertinggi & 88 & 89 \\
Nilai terendah & 76 & 76 \\
Mean & 80,81 & 82,66 \\
Median & 80 & 82 \\
Mode & 79 & 80 \\
\hline Jumlah & 2586 & 2645 \\
\hline
\end{tabular}

\section{Data Motivasi Belajar Kelas Kontrol}

Data motivasi pretest diperoleh dari angket sebelum penerapan produk pengembangan, sedangkan data motivasi post test diperoleh dari angket setelah penerapan produk pengembangan. Angket antara pretest dan post test berisi indikator dan butir pernyataan yang sama.

Data motivasi belajar pada pembelajaran dari 32 peserta didik kelas kontrol selanjutnya dihitung dan di konversi ke data kualitatif skala lima. Data motivasi belajar kelas kontrol dapat ditampilkan pada Tabel 6.

Tabel 6. Tabulasi Data Motivasi Kelas Kontrol

\begin{tabular}{lcc}
\hline Keterangan & Pretest & Post test \\
\hline Nilai tertinggi & 131 & 131 \\
Nilai terendah & 104 & 103 \\
Mean & 116,47 & 117,41 \\
Median & 116 & 118 \\
Mode & 106 & 118 \\
\hline Jumlah & 3727 & 3757 \\
\hline
\end{tabular}

Berdasarkan perbandingan motivasi belajar pretest dengan post test pada data di atas dapat diketahui bahwa terjadi peningkatan motivasi belajar. Hal ini terlihat dari selisih jumlah pretest dengan post test sebesar 30 poin, dan bernilai positif, sehingga dapat dikatakan terdapat peningkatan motivasi belajar pada kelas kontrol.

\section{Data Motivasi Belajar Kelas Eksperimen}

Data motivasi belajar pada pembelajaran dari 32 peserta didik kelas eksperimen selanjutnya dihitung dan di konversi ke data kualitatif skala lima. Data motivasi belajar kelas eksperimen disajikan pada Tabel 7.

Tabel 7. Tabulasi Data Motivasi Kelas Eksperimen.

\begin{tabular}{lcc}
\hline Keterangan & Pretest & Post test \\
\hline Nilai tertinggi & 140 & 141 \\
Nilai terendah & 105 & 107 \\
Mean & 118,56 & 119,47 \\
Median & 117 & 118 \\
Mode & 108 & 116 \\
\hline Jumlah & 3794 & 3823 \\
\hline
\end{tabular}

Berdasarkan data tersebut dapat dilihat adanya selisih nilai motivasi antara pretest dengan post test sebesar 29, dan bernilai positif. Dengan demikian, dapat disimpulkan bahwa terjadi peningkatan motivasi belajar pada kelas eksperimen.

\section{Analisis Data}

\section{Analisis Data Hasil Belajar}

Analisis ini dilakukan untuk mengetahui perbedaan prestasi belajar peserta didik antara kelas eksperimen dan kelas kontrol dengan membandingkan nilai gain (penguatan) hasil belajar kelompok kontrol dengan kelompok eksperimen. Nilai gain didapatkan dengan membandingkan hasil post test dikurangi pretest dari kelompok eksperimen ataupun kelompok kontrol. Hipotesis yang diuji adalah, $\mathrm{H}_{0}$ : Hasil belajar peserta didik dalam pembelajaran menggunakan portal e-learning yang memanfaatkan fasilitas vicon lebih kecil atau sama dengan peserta didik yang tidak memanfaatkan fasilitas vicon. $\mathrm{H}_{1}$ : Hasil belajar peserta didik dalam pembelajaran menggunakan portal e-learning yang memanfaatkan fasilitas vicon lebih besar dari peserta didik yang tidak memanfaatkan fasilitas vicon. Sebelum uji t dilakukan terlebih dahulu dilakukan uji prasyarat yaitu pengujian normalitas data dan uji homogenitas. Setelah data dipastikan terdistribusi normal dan homogen, kemudian dilakukan uji t. Analisis uji t menggunakan independent sample t test, taraf sig- 
nifikansi 0,05. Memakai independent sample $t$ test karena data yang di uji berasal dari sampel yang berbeda, yaitu kelas kontrol dan eksperimen.

Hasil pengujian menunjukkan bahwa nilai sig (2-tailed) 0,424 . Karena pengujian Uji t menggunakan pihak kanan, maka:

$$
\frac{\text { sig }(2-\text { tailed })}{2}=0,212 \text {. }
$$

Menurut ketentuan uji t, sig $(0,212)>0,05$, dengan demikian menerima $\mathrm{H}_{0}$, yaitu hasil belajar peserta didik dengan memanfaatkan vicon sama dengan hasil belajar peserta didik yang tidak menggunakan vicon. Data pengujian tersebut diketahui tidak ada perbedaan nilai penguatan hasil belajar yang signifikan pada kelas kontrol dan kelas eksperimen, namun jika dilihat dari data gain (penguatan) terdapat perbedaan nilai gain, untuk kelas kontrol sebesar 31 poin, untuk kelompok eksperimen 59. Dari kelompok kontrol dan eksperimen dapat diketahui perbedaan gain antara kelas eksperimen dan kontrol sebesar 28.

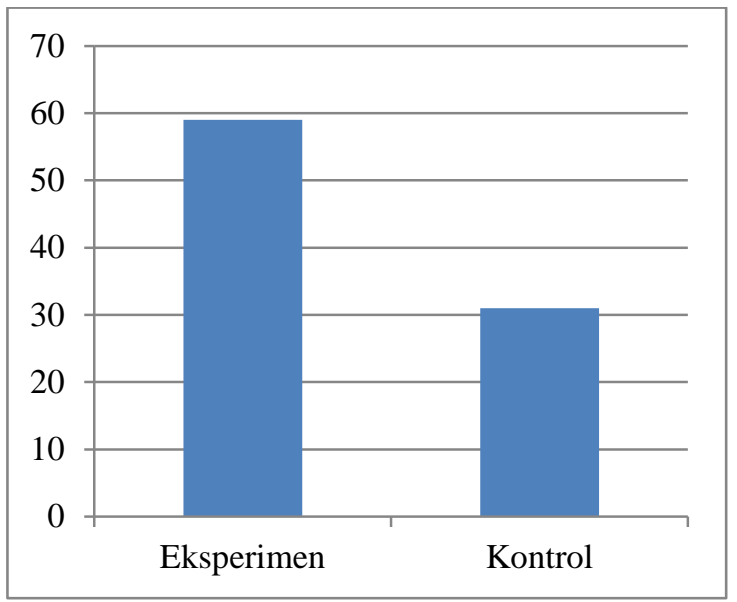

Gambar 3. Gain Hasil Belajar Kelas Eksperimen dan Kontrol

Menurut data pengujian SPSS rata-rata hasil belajar peserta didik yang menggunakan fasilitas vicon lebih besar dari pada peserta didik yang tidak menggunakan vicon.

\section{Analisis Data Motivasi Belajar}

Tujuan uji t pada motivasi belajar adalah untuk mengetahui perbedaan motivasi setelah dilakukan pembelajaran baik pada kelompok kontrol maupun kelompok eksperimen. Sebelum dilakukan uji $t$ terlebih dahulu dilakukan uji prasyarat, yaitu uji normalitas data dan homogenitas. Setelah data dipastikan terdistribusi normal dan homogen, kemudian dilakukan uji t. Uji t menggunakan Independent-Sample $t$ test, dengan taraf signifikansi 0,05. Uji t menggunakan IndependentSample $t$ test karena data nilai motivasi yang didapatkan berasal dari subjek yang berbeda, yaitu kelompok kontrol dan eksperimen. Hasil uji t dengan SPSS didapatkan sig (2-tailed), bernilai 0,286 , karena menggunakan uji kanan maka:

$$
\frac{\text { sig }(2 \text {-tailed })}{2}=0,143 \text {. }
$$

Berdasarkan ke-tentuan uji t, maka menerima $\mathrm{H}_{0}$, menolak $\mathrm{H}_{1}$, yang artinya motivasi siswa dari kelompok eksperimen dan kontrol sama. Hasil perbandingan gain motivasi kelas kontrol dan eksperimen dapat dilihat pada Gambar 4

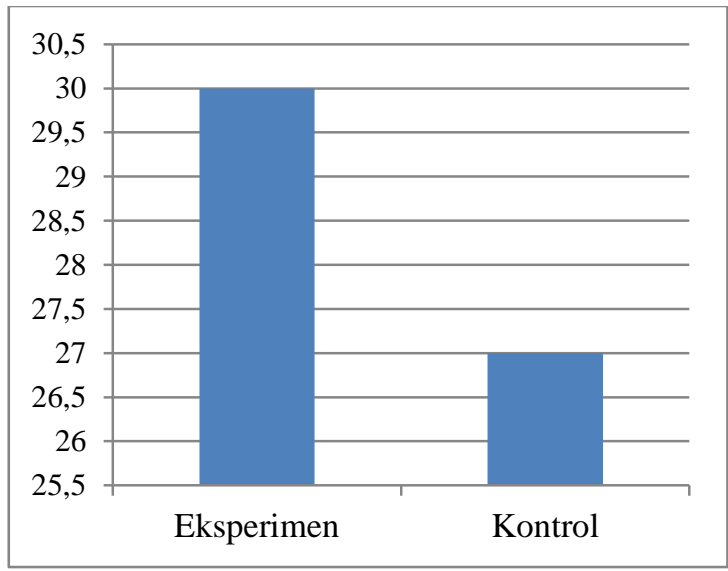

Gambar 4. Gain Motivasi Belajar Kelas Eksperimen dan Kelas Kontrol

\section{SIMPULAN DAN SARAN}

\section{Simpulan}

Berdasarkan penelitian dan pengembangan produk portal e-learning dengan vicon yang sudah dilakukan dapat diambil kesimpulan sebagai berikut.

Pertama, spesifikasi produk portal elearning yang dikembangkan di SMK Muhammadiyah 1 Bambanglipuro yaitu: (a) Portal e-learning menggunakan LMS Moodle terintegrasi dengan BigBlueButton, sehingga memungkinkan pengguna untuk melakukan video conference; (b) portal e-learning yang dikembangkan terdiri dari 5 menu kompetensi 
keahlian, yaitu Teknik Kendaraan Ringan, Teknik Sepeda Motor, Multimedia, Rekayasa Perangkat Lunak, Pengolahan Hasil Pertanian. (c) Jumlah pengguna yang diunggah dalam produk portal e-learning berjumlah 575 account yang terdiri atas staf pengajar dan peserta didik dari masing-masing kompetensi keahlian; (d) Produk portal e-learning dapat dibuka pada browser google chrome, Mozilla fire fox, dan internet explorer.

Kedua, kelayakan portal e-learning menggunakan LMS Moodle dengan vicon di SMK Muhammadiyah 1 Bambanglipuro, untuk validasi alpha didapatkaan skor rerata 4,05 dengan kategori baik. Uji beta didapatkan skor rerata 3,87 dengan kategori baik. Untuk ahli materi didapatkan skor rerata 3,53 dengan kategori baik. Produk pengembangan portal $e$ learning dengan vicon di SMK Muhammadiyah Bambanglipuro layak untuk diterapkan pada pembelajaran secara luas.

Ketiga, hasil belajar peserta didik dalam pembelajaran menggunakan portal $e$ learning yang memanfaatkan fasilitas video conference tidak lebih tinggi dari hasil belajar peserta didik yang tidak memanfaatkan fasilitas video conference, dari hasil pengujian didapatkan hasil belajar antara kelas eksperimen dan kontrol sama. Hasil uji t didapatkan sig(one-tailed), bernilai 0,212 , berdasarkan ketentuan tidak terdapat perbedaan yang signifikan hasil belajar antara kelas kontrol dan kelas eksperimen.

Keempat, motivasi peserta didik dalam pembelajaran menggunakan portal e-learning yang memanfaatkan fasilitas video conference tidak lebih tinggi dari motivasi belajar peserta didik yang tidak memanfaatkan fasilitas video conference, dari hasil pengujian didapatkan motivasi belajar kelas kontrol dan eksperimen sama. Hasil uji t didapatkan sig (one-tailed), bernilai 0,143 , menurut ketentuan pengujian, tidak ada perbedaan motivasi baik kelas kontrol maupun eksperimen.

\section{Saran}

Saran untuk pemanfaatan produk pengembangan portal e-learning dengan vicon adalah: (1) sekolah dan guru dapat memanfaatkan media pembelajaran e-learning sebagai salah satu solusi pemanfaatan internet sebagai sumber dan media belajar; (2) fitur video conference yang terintegrasi dengan portal e-learning ini dapat dimanfaatkan oleh guru sebagai sarana pembelajaran alternative jarak jauh. Dengan adanya fitur ini diharapkan guru yang berhalangan hadir karena tugas sekolah atau keperluan lain dapat tetap bertatap muka dengan siswa tanpa harus hadir di kelas. Pemanfaatan vicon akan lebih maksimal dengan desain pembelajaran yang sudah direncanakan sebelumnya; (3) SMK Muhammadiyah 1 Bambanglipuro sebagai sekolah swasta unggulan diharapkan dapat segera menerapkan portal e-learning karena dengan adanya portal e-learning ini mampu menambah fasilitas belajar berbasis web disekolah.

\section{DAFTAR PUSTAKA}

Alberta. (2006). Video-conferencing research community of practice research report. Edmonton: Alberta Education.

Alessi, Stephen M. \& Trollip, Stanley R. (2001). Multimedia for learning, methods and development ( $3^{\text {rd }} E d$.). Massachusetts: Allyn and Bacon.

Bello, O.W. et al. (2014). Towards the design of a synchronous virtual learning system. Journal of Informatics and Communication Technology (CJICT) Vol. 2, No. 2, December, 2014, pp: 5974.

Candarli, D., Yuksel, H.G. (2012). Students' perceptions of video-conferencing in the classrooms in higher education. Journal Social and Behavioral Sciences, 47, (2012), 357 - 361.

Gough, M. (2006). Video conferencing over ipconfigure, secure, and troubleshoot. Syngress Publishing, Inc: Canada.

Henderson, A.J. (2003). The e-learning question and answer book. New York: Amacom.

Karal, H., Cebi, A., Turgut, Y.E. (2011). Perceptions of students who take synchronous courses through video conferencing about distance education. The Turkish Online Journal of Educational Technology - October 2011, volume 10 Issue 4, pp: 276-293.

Laipaka, R., Sarwoko, E.A. (2011). Development of web-based e-learning with pedagogy concept. International Conference on Information Systems For Busi- 
ness Competitiveness (ICISBC) 2011, pp: 68-74.

Mayer, R., Clark, R.C. (2008). E-learning and the science of instruction. John Wiley \& Sons, Inc: USA.

Meegama, R.G.N, et al. (2015). Use of cloudbased services for higher education in developing countries. International Conference on Education and Distance Learning, Colombo, 2015.

Meriläinen et al. (2013). The best on-line guidance experiences in finnish primary school teacher education practicum. The Online Journal of Distance Education and e-Learning. Volume 1, Issue 1, January 2013, pp: 20-25.

Moore, J.L., Deane, C.D., Galyen, K. (2011). E-learning, online learning, and distance learning environments: are they the same?. Journal Internet and Higher Education 14 (2011) 129-135, University of Missouri.

Naidu, S. (2003). E-learning, a guidebook of principles, procedures and practices. New Delhi: CEMCA.

Paderanga, L.D. (2014). Classroom video conferencing: Its contribution to peace education. Journal Social and Behavioral Sciences 123 ( 2014 ). 113 - 121.

Rosenberg, R. (2009). Video conferencing in distance learning: a New Zealand schools' perspective. Journal of Distance Learning, 2009, 13(1), 91-107

Sahana, S. (2015). E-society and on-line communities. International Journal of Advanced Research in Computer Science and Software Engineering. Volume 5, Issue 3, March 2015, pp: 244246.
Saraswat, S. (2014). Customization and implementation of LMS moodle. International Journal of Scientific and Research Publications, Volume 4, Issue 5, May 2014, pp: 1-4.

Seeling, P. (2010). Web conferencing traffic an analysis using dimdim as example. International Journal of Computer Networks \& Communications (IJCNC) Vol.2, No.6, November 2010, pp: 1-10.

Surjono, H. D. (1998). Sistem ABC: perangkat lunak untuk membuat program CAI. Jurnal PTK, No.2 (VII), 35-38.

Syamsuddin, I., Alimin. (2014). Assessing moodle as learning management system platform for english course based TOEFL. International Journal of Computer Trends and Technology (IJCTT), Volume 18 Number 6, Dec 2014.

Tandirerung, Veronika. (2014). Implementasi e-learning program keahlian TKJ di SMK DIY pasca pembubaran RSBI. Jurnal Pendidikan Vokasi, Vol 4, Nomor 1, Februari 2014, pp: 96-110.

Thabit, W. (2013). Blended learning approach using moodle and student's achievement at Sultan Qaboos University in Oman. Journal of Education and Learning; Vol. 2, No. 3; 2013, pp: 96110.

Zhang, S., Zhou, L., Briggs, R.O. (2006). Instructional video in e-learning: assessing the impact of interactive video on learning effectiveness. Information \& Management 43 (2006) pp: 15-27.

Zrakić, et al. (2012). providing adaptivity in moodle LMS courses. Journal Educational Technology \& Society, 15 (1), 326-338. 